\title{
Infertility and Surrogacy in Islamic Society: Socio-Cultural, Psychological, Ethical, and Religious Dilemmas
}

\author{
Aref Abu-Rabia*
}

Ben-Gurion University of the Negev, Beer-Sheva 84105, Israel

\begin{abstract}
The effects of infertility on individuals and its emotional, psychological, and social consequences are complex matters that are influenced by many variables. Research now indicates that most cases of infertility can be attributed to a physiological cause in the man or woman. Shari'a is the Islamic way of life, of which medicine is an integral part. The Prophet Muhammad provided the foundation for a medical tradition that related to human beings in their totality; the spiritual, the psychological, and the physical were considered within the context of the social milieu. The Prophet described marriage as being half of the religion, so in Islam children are considered a great and blessed gift of Allah. Despite the high prevalence of male infertility, infertility is usually considered the woman's problem. Thus, the role of male infertility is vastly under-appreciated and even under-reported in Middle Eastern societies. Medical intervention is in keeping with the Islamic tradition; there are no religious objections in Islamic codes of ethics to an infertile couple pursuing medical treatment for infertility. This paper attempts to build a self-contained argument vis-à-vis infertility and surrogacy from Sunni-Islamic perspectives, taking into account socio-cultural and psychological aspects of this issue. It is based on primary and secondary sources, interviews with couples who have participated in these treatments, the opinions of religious leaders and healers, as well as archival and documentary material, and a review of published and unpublished materials, books, and scientific journals.
\end{abstract}

Keywords: Infertility, culture, psychology, Sunni, Islam, surrogacy, ethics and medicine, Middle East.

\section{BACKGROUND}

The Prophet Muhammad described marriage as half of the faith (al-zawaj nisf al-iman). There are two main functions of marriage in Islam: legitimate sexual gratification and procreation. Thus, children in Islam are considered a great and blessed gift of Allah: "Wealth and children are an ornament of life of the world" [1]. Procreation is also a sacred right in Islam; it is one of the five basic goals (daruriyat) of Islamic law, in addition to the preservation of religion, self, mind, and property [2]. The Prophet Muhammad said: "Marry women who will love you and give birth to many children for I shall take pride in the great number of my Ummah on the Day of Judgment" [3].

According to Islam, procreation of children, whether boys or girls, as well as infertility are both determined by the will of Allah: "To Allah belongs the dominion of the heavens and the earth. He creates what He wills (and plans). He bestows (children) male or female according to His Will (and plan), or He bestows both males and females, and He leaves barren whom He will: for He is full of Knowledge and Power" [1]. The Qur'an makes reference to two Prophets, Ibra$\mathrm{him} /$ Avraham and Zakariyya, whose wives could not at first bear children, but eventually, did so in old age [1].

*Address correspondence to this author at the Ben-Gurion University of the Negev, Beer-Sheva, 84105, Israel; Tel: 0544292892; Fax: 08-6472952;

E-mail: arefabu@gmail.com
These examples send a message that married couples may not be able to bear children now, but may later succeed in doing so, despite their difficulties, should it be the will of Allah. If one is certain, after exhausting all permissible avenues of medical intervention, that conception is impossible, one should accept that this fate is also the will of Allah, since only He has the power to initiate conception. In Muslim societies, religion still has a powerful meaning and greatly influences behavior, practices and policy-making [4].

Fertility is a topic of crucial importance in society. While infertility is defined as the diminished or total absence of the ability to produce offspring, in either gender, it is not as irrevocable a condition as sterility [5]. Female infertility may result from congenital defects such as lack of or blockage of the fallopian tubes; failure to ovulate; an allergic reaction to the proteins in the semen; or even ovulation during periods of the month when sexual intercourse is prohibited. Sometimes, the female is born without a uterus and fertility is virtually nonexistent [6].

According to World Health Organization data, infertility affects approximately eight to twelve percent of couples of reproductive age (e.g., ages 15-49) worldwide [7]. Thus, infertility is a global health issue that affects approximately 80 million people worldwide, more than half of whom are Muslims [8,9]. In Middle Eastern countries, infertility is expected to affect between ten and fifteen percent of married couples [4]. Ethnographic research conducted by Inhorn [10] 
indicates that, contrary to popular belief, infertility is more commonly found in men than women among couples in childless Middle Eastern marriages. Inhorn documents the marital, moral, and material commitments of couples undergoing assisted reproduction, revealing how new technologies are transforming their lives and religious sensibilities. Moreover, she examines the changing manhood of husbands who undertake transnational "egg quests" against the backdrop of war and economic uncertainty, out of devotion to the infertile wives they love.

\section{SOCIAL, CULTURAL, AND PSYCHOLOGICAL CONSEQUENCES}

For most people, having children is an essential part of life. When couples are unable to have children, there can be various emotional, psychological, and social consequences. Today there are approximately 80 million involuntarily childless persons on our planet. Approximately 5\% of couples living in the developed world experience infertility. The effects of infertility on individuals are influenced by many physical variables. At the same time, the social significance and psychological importance of children differs from society to society and from era to era. In most societies, childlessness is a great problem that leads to much suffering and has many negative social consequences, especially for women. The situation of childlessness is in many ways culturally defined, so treatments and solutions must fit sociocultural contexts [11].

Research now indicates that most cases of infertility can be attributed to a physiological cause in the man or woman. Approximately one-third of the time a physiological problem is identified in the woman, one-third of the time in the man, and about one-tenth of the time in both partners. In some ten to twenty percent of cases, the cause of infertility cannot be determined. But while the causes of infertility are overwhelmingly physiological, the resulting heartache, often exacerbated by the physical and emotional rigors of infertility treatment, may exact a huge psychological toll. Infertile couples often experience reactions that include shock, grief, depression, anger, and frustration, as well as loss of selfesteem, self-confidence, and a sense of control over their destiny. Infertile couples may also struggle with anxietyrelated sexual dysfunction and other marital issues [12].

Having children within Middle Eastern communities is expected and not having children lowers social status. If a couple remains childless, it does not meet social desired expectations and does not obtain the higher status awarded to parents in their society. As a result of this situation, both men and women bear a psychological burden when pregnancy does not occur. In most cases, there are gender-specific consequences related to the assumed causes of fertility problems [13]. For example, blaming the woman for not being able to conceive strongly intensifies the psychological burden on women [14]. For men, the additional burden derives from the fact that having children is also a public expression of their virility, which leads to social recognition of their masculinity and thereby legitimizes their sense of honor. Consequently, not having children affects their sense of honor $[15,16]$. The psychological burden on men is also influenced by the fact that they are not able to continue the patrilineal family line [13].

\section{TRADITIONAL ATTITUDES AND BELIEFS ABOUT INFERTILITY}

Despite the high prevalence of male infertility, it is usually considered to be the woman's problem. Thus, the extent of male infertility is vastly under-appreciated and the condition is under-reported (e.g., hidden) in many societies. Childlessness in Middle Eastern societies may not be politely skirted as a 'delicate private matter.' It is not only a source of personal pain for the couple, but can also become the subject of gossip in the community. Infertile couples are excluded from social events, shunned or criticized, cursed and mistreated, and lose self-esteem. A woman's infertility may lead to divorce, invite polygamous marriage, and cause social isolation, loneliness, and despair $[17,18]$. Furthermore, in the Middle East the infertile Muslim woman is viewed as a danger, i.e., as a potential source of harm to the children of others, due to the belief that envy can lead her to cast an evil eye on the offspring of others. Therefore, she may be shunned by fertile women who fear for their own children's safety [19, 20]. Infertile women face a gloomy future, fearing that their husbands will take second wives [21]. A childless wife's house is considered unblessed and is therefore avoided; it is never used as an informal gathering place for women [22]. She is often viewed as 'accursed by God' or a 'victim of witchcraft or sorcery.' Some childless wives feel that there is no place for them in Islam or in their own community. The infertile wife feels anxious and suffers from grief, fear, domestic violence [23], economic deprivation, and polygamy, and may even undergo life-threatening medical intervention [24]. In most cases, for instance in Arab-Bedouin societies, men do not divorce a childless wife when they take a new (e.g., a second) wife. There can be numerous reasons for this. The first marriage may be an exchange marriage (badal) [25], intended to fulfil mutual Arab-Bedouin tribal obligations and designed to prevent the existence of unmarried women who would jeopardize tribal honour. Another possible reason is that the childless wife may become pregnant after five or even ten years [26, 27]. During these years, as she waits to conceive, she helps her co-wife and shares household labours and this contribution is needed and appreciated in society. Yet, if the new wife bears children, particularly male offspring, the child-bearing wife's status will become higher than that of the childless wife.

\section{TRADITIONAL SOLUTIONS TO INFERTILITY}

One ancient and long-standing solution to infertility in Middle Eastern societies has been polygamous marriage. This practice (sometimes called surrogacy) is described in the Bible in the case of Sara and Abraham with Hagar, who bore a son, Ishmael, for Abraham [28]. Similarly, Rachel used her slave girl, Bilha, to bear a child for Jacob [28]. According to Smith [29], in ancient Arabia, a husband was so indifferent to his wife's fidelity that he might send her to cohabit with another man to acquire a 'good seed.' Nikah alistibda' is a kind of sexual intercourse that was performed in the Jahiliyya, through which the woman sought to have intercourse with a specific man only for the purpose of having a child from him [30]. The findings of Peters [31] regarding the incapacity of men [32] to produce offspring among the Arab-Bedouin of Cyrenaica in the current period are notable: if a husband is convinced that he is infertile, it may lead him 
to delegate a kinsman to serve his wife for procreative purposes. The wife is required to submit. Another alternative, if he is not to die without issue, is to 'take' a son from his brother and subsequently fulfil paternal obligations towards this boy, namely, to attend to his circumcision, provide him with teaching in the Qur'an, and give him the wealth with which to marry [31]. The regret voiced about a childless couple is that they have no one to fetch and carry for them. A man without sons may 'borrow' one of his brothers' or sisters' small sons, rewarding him later in life with a gift of animals or by making him his heir [31]. According to Bailey [27], among the Arab-Bedouin of the Negev and Sinai there is a proverb that says: "He who leaves offspring doesn't die, unless his offspring are daughters" (illi 'aggab ma mat ghayr illi 'igbih banat).

Muslims in different parts of the globe respond to infertility in different ways. They beseech Allah, asking for intercession (shafa'ah) and treatment, and seek relief through traditional medicine [33-38]. In some cases fertility will be restored to an infertile woman following a prescribed ritual or the use of traditional medicine [39]. Such a response to infertility takes place as reflected in two well-known and accepted sentiments among Muslims: the first is the wellknown phrase in the Qur'an: "Say: 'Nothing will happen to us except what Allah has decreed for us: He is our Protector: and on Allah let the Believers put their trust" [1], and the second is the Prophet Muhammad's proclamation that "No disease Allah created, but that He created treatment" [40].

\section{MODERN SOLUTIONS TO INFERTILITY}

In vitro fertilization (IVF) [41] is a modern biomedical technique that assists couples who may otherwise be unable to achieve a pregnancy through other natural or technologically-assisted means. IVF is generally used when, due to some obstruction, the sperm of the husband cannot reach the ovum. In this case, the ovum is removed from the woman's ovary at the time of ovulation, and exposed to the husband's sperm [42] in vitro in hopes that it will be fertilized. The fertilized ovum is then preserved in a test tube and at a later stage, when it becomes an embryo, is implanted in the woman's uterus. Thus, women who otherwise would not be able to conceive a child are able to carry to term the fetus conceived outside the body and give birth to biological offspring $[43,44]$.

\section{MUSLIM ATTITUDES TO MODERN SOLUTIONS TO INFERTILITY}

Since Islam attaches great importance to marriage and family life, there is usually no objection to artificial insemination [45], provided there are safeguards to ensure the sperm is the husband's. Modern Sunni-Muslim jurists have addressed IVF methods in the light of the $\operatorname{shari~}^{-} a$ ruling that in vitro fertilization is permissible as long as the semen [46] and ovum are from a man and woman who are legally married and fertilization takes place during their marriage, not after divorce or the death of the husband [47, 48]. These opinions stipulate that in vitro fertilization is permissible as long as the fertilized ovum placed in the womb of the woman is an egg taken from her own ovaries, meaning that there is no surrogate mother. The physician must be a trusted female
Muslim physician wherever possible and both the wife and her husband must consent to this kind of fertilization. One should note that there are IVF clinics in Middle Eastern countries that treat infertile couples. However, the financial cost to couples is high, and treatment may take years before producing positive results. Such IVF procedures must be carried out according to certain Islamic ethical stipulations regarding the interaction between patient and physician: one should not expose one's private parts ('awra) to the gaze, let alone touch, of someone other than one's spouse, except where necessary [49]. Introducing an egg or sperm from a third party into the equation is akin to 'sharing the marriage bed' with someone else and therefore is considered tantamount to adultery (zina) [50].

Donor sperm pregnancies are strictly forbidden in all schools of Islamic law [51]. Giving the embryo to another woman to carry the pregnancy in her womb, i.e., surrogacy (dhi'r, um badilah) [52] is prohibited under Islamic law. Nevertheless, the advent of egg donation and surrogacy in modern medicine has led several jurists to allow surrogacy between two co-wives of the same husband. Their reasoning is that if maternal lineage is confirmed by strict laboratory control and trusted physicians, then the implanted embryo would be from sperm that is permissible for the surrogate mother, and she would be acting as a nourisher for the fetus, which is analogous to a wet-nurse. Such rulings stipulate that the surrogate wife must have her own children and agree to assist her co-wife and that the first wife (who gives the egg) has no uterus but can produce ova [53]. These jurists assert that the wife who provided the egg is the mother, but others hold that the wife who gives birth to the child is the mother, citing the Qur'an: "none can be their mothers except those who gave them birth" [1]. In any case, in 1985 the Islamic Fiqh Council reversed its original 1984 ruling permitting surrogacy, thus forbidding surrogacy between co-wives [54].

The Islamic Fiqh Council [54], after reviewing all the research submitted on in vitro fertilization and after consulting experts in the field, concluded that five forms of in vitro fertilization are prohibited and two are lawful under Islamic law. The five procedures that are completely illegal because they result in confusion (ikhtilāt al-ansāb) [55] regarding parentage are the following:

1. Fertilization that is the product of the sperm of a husband and the ovum of a woman other than his wife, where the embryo is then implanted in his wife's uterus, e.g., egg donorship.

2. Fertilization that is the product of a woman's ovum by the sperm of a man other than her husband, where the embryo is subsequently implanted in the woman's own uterus, i.e., sperm donorship.

3. Fertilization that is the product of the sperm of a husband and the ovum of his wife, where the embryo is implanted in the uterus of a surrogate mother.

4. Fertilization that is the product of the sperm and ovum of two individuals other than the couple who want to conceive a baby, where the embryo is implanted in the wife's uterus, that is, egg and sperm donorship.

5. Fertilization that is the product of the sperm of a man who has two wives and the ovum originates with one 
wife, while the embryo is implanted in the uterus of the other wife.

The following two in vitro fertilization procedures are lawful under Sunni-Islam:

1. Fertilization that is the product of the husband's sperm and the wife's ovum (sahibay al-nutfa wal-buwayda) achieved outside the body, where the embryo is then inserted into the wife's uterus.

2. Fertilization that is the product of the husband's sperm being mechanically inserted into his wife's uterus so that the fertilization takes place inside her body.

We can conclude from the description of the above procedures for treating infertility that surrogacy is not allowed in Islam in any of its forms.

\section{DISCUSSION}

The entwining of gender and kinship allows people to view women in terms of family, and defines relationships with women through their roles as mothers and wives [56]. Marriage is an important cultural institution, one that determines a woman's value or social capital. Fertility is greatly valued in Arab culture [57]. The shari'a affirms the importance of marriage, family, and procreation. Treatment of an infertile couple is, therefore, encouraged when it becomes a necessity, because it makes procreation possible [8].

Sunni Muslims believe that surrogate motherhood (euphemistically referred to as hiring a womb) in the West is prompted not only by what is viewed as the legitimate desire of couples to have children. Sunni Muslims believe that there are Western women who choose this option solely on grounds of convenience or vanity. It may be done free of charge or with suitable monetary remuneration for services rendered. Individuals may resort to this procedure either because a married woman who desires to have a child has problems carrying her fetus to full term, or for reasons of convenience or comfort, because the woman simply wishes to forgo the 'trouble' of conception, gestation, and labor, to relieve herself of maternal burdens, to avoid jeopardizing her beauty and youthful looks [58], or as a matter of self-indulgence $[59,60]$. It is argued that should surrogacy be permitted in Islam, well-to-do women who want to maintain their shape and to keep their bodies as fresh as the boughs of the horse radish tree [61] might hire surrogates to bring babies into the world. Others say, in a similar spirit, that "her waist and breast (chest) will not change" as a result of avoiding pregnancy, childbirth, and breastfeeding [59].

According to the precepts of the shari'a, surrogate motherhood as described above is prohibited, since it involves the introduction of the sperm of a male into the uterus of a woman to whom he is not married and, thus, clearly falls under the specific category of transgressing the bounds of Allah as stated in the Qur'an [1]. Between co-wives, such surrogacy brings hope to childless Muslim couples, but this method raises a number of ethical and legal questions and therefore has not received blanket approval. It is argued that introducing a third party into the family equation could result in the confusion of parentage [6]. Allah says: "It is He who has created man from water: then has He established relation- ships of lineage and marriage: for thy Lord has power (over all things)" [1]. Islamic law dictates that every child has the right to legitimacy and should know who his father and his mother are. The Prophet said: "The child is to be attributed to one on whose bed he is born, and for a fornicator there is stoning" [62]. According to Islam, children must be attributed to their fathers, i.e., affiliation hinges on the paternal line: "Call them by (the names of) their fathers: that is juster in the sight of Allah. But if ye know not their father's (names, call them) your Brothers in Faith, or your Maulas. But there is no blame on ye if ye make a mistake therein: [what counts is] the intention of your hearts: and Allah is Oft-Forgiving, Most Merciful" [1].

Can Islamic law justify the use of the sperm of someone other than the husband for artificially inseminating a wife? In this regard, Sheikh Mahmud Shaltut issued a special fatwa condemning this procedure and equating it to an act of adultery, stating that "[a]rtificial insemination with the sperm of a stranger under the shari ' $a$ is a grievous crime and a great sin and is tantamount to adultery" [50]. Al-Qaradawi [63] and other important Muslim muftis who have addressed the question of artificial insemination with donor sperm have been unequivocal on this issue. Al-Qaradawi stated that: "Islam safeguards lineage by prohibiting adultery, fornication (zina) and legal adoption, thus keeping the family lineage unambiguously defined, without any foreign element entering into it. It likewise prohibits what is known as artificial insemination, if the donor of the sperm is someone other than the husband."

According to al-Qaradawi [64], the offspring's mother is the woman from whom the egg was taken (e.g., not a surrogate mother) and from that egg the embryo will develop. The baby must belong to this woman, and she has the fullest right to raise the infant. Others, such as Dr. Ali Gommah (Mufti of Egypt) have stressed the utmost importance of children being affiliated with their biological parents, arguing that all practices that might lead to confusion about descent, such as surrogacy and adoption, should be prohibited [65]. Since every child in Islam has a right to a definite parentage, namely, that of a biological father and biological mother, in the case of surrogacy the question arises as to the identity of the real mother of a child thus conceived. Is the mother the genetic mother who provides the egg from which the child is born? Or is she the woman whose womb serves as a carrier for the child? Such confusion is bound to affect the child emotionally, as s/he will be torn between two mothers. Finally, one cannot ignore that the fact that the entire surrogate procedure amounts to dehumanizing the process of human procreation by reducing the womb to the level of a commodity that can be bought or rented as a service. Ultimately, such a process, yet again, violates the dignity and honor [66] that Allah Almighty has bestowed on men and women [67]. Furthermore, it may also lead to legal battles over the parentage of the child and custody issues, as has happened in the United States and other countries in the West [68,69], where surrogate mothers refused to hand over babies they have carried and given birth to, despite previous agreements, insisting that they were the rightful mothers of the child $[70,43]$. Further questions arise as to whether one is permitted to use sperm or eggs that have been stored or 'frozen' after the death of the sperm 'owner' [71]. 
Most Shiite religious leaders support the Sunni views that third-party donations are forbidden. However, in 1999, Ayatollah Khamane'i, the Supreme Jurisprudent of the Shi'a in Iran, issued a fatwa permitting a wider use of donor technologies than the two cited above by the Islamic Fiqh Council. Khamane'i ruled that egg, sperm, and gamete donation and surrogacy are allowed under certain conditions [70, 72]. For example, egg donation is allowed as long as the husband marries the egg donor temporarily, thereby ensuring that all three parties are married [73]. It is worth noting that temporary marriage (mut'a) [74], a form of time-limited union, is permitted among the Shi'a [75]. Khamanei's justification for allowing embryo donation is that the embryo comes from a married couple and is given to another married couple, and that the procedure does not involve direct bodily sexual contact that would constitute an adulterous relationship. It is worth noting as well that some of the egg donors were friends or relatives, members of the agnatic group of the infertile couples [76, 77].

Reproductive choice within Islamic societies is affected by diverse contexts, norms, and cultures, as well as by Islam. The desire for children may lead deeply religious people to make decisions contrary to religious teachings [53]. Some Muslim couples cross national borders to fulfill a reproductive choice that may not be permitted in their own society or country [4]. This has been the case for an unknown number of Sunni Muslim couples from different Middle Eastern countries who, in order to become parents, have sought donor gametes in IVF clinics in Lebanon, thereby going against the fatwas of orthodox Sunni jurists who categorically forbid the use of third-party reproductive practices [76, 77].

Sunni jurists compare seeking donor gametes to adultery (zina) as a violation of fidelity, arguing that it changes the biological relationship between parents and offspring and threatens the integrity of lineage or kinship. Only a minority of religious authorities permits surrogacy between co-wives [60], and there is still considerable debate on this matter among Islamic jurists. For example, Dr. 'Abd al-Mu'ti alBayumi, Dean of the Faculty of Theology at al-Azhar University and member of the religious council, who issued a fatwa that allows relatives to hire wombs within the family (between mother and her daughter, or between co-wives of the same husband. This controversial fatwa was discussed by the Egyptian parliament (majlis al-sha'b) $[78,79]$. The debate over surrogacy has recently been re-opened among Sunni scholars. While some religious authorities think that surrogacy could be practiced, others believe that it should not be approved because of the many social, cultural, and legal problems associated with it $[80,60]$.

Childless Muslims are encouraged by Islamic sources to foster orphans [81], as portrayed in the Prophetic hadith: "The best house of Muslims is one where an orphan is cared for."The foster parents are precluded from legally adopting the orphan because adoption is forbidden in Islam [1] "Allah has not made any man two hearts in his (one) body". In traditional Islamic societies, a childless couple often brings up a relative's child. Some couples choose to take foster children who are close blood kin, particularly offspring of their own siblings.
In some cases, the problem of an infertile wife is solved by marriage to a second wife. The offspring of the man's second wife are legally accepted under Islamic law and are raised in the framework of a polygenic marriage and extended household. The customary focus on the traditional family as the basic stable unit of society provides another solution for childless couples. Another future solution for childless Muslims may be medical: further clinical experience and advances in surgical techniques could make uterine transplantation $[43,82,83]$ a reality in the treatment of infertility sometime in the future. Such a procedure would be especially attractive to Muslim communities where the concept of surrogate-mother and the donation of sperm, egg, or embryo are completely unacceptable from a religious and ethical viewpoint.

Anthropologists claim that women's bodies in Middle Eastern culture are perceived as fertile wombs; consequently, the womb becomes the focus for symbolic rituals purported to increase fertility. Thus, the Islamic concept of maternal origins residing in 'one womb' does not run counter to paternity and in a sense serves to reinforce the definition of paternity [31]. At the same time, the impact of the 'one womb' concept is a key element in the context of social cohesion that goes beyond the family; the son is of the blood of the father but all bonds of kinship are expressed in Arabic by the term of womb (rahim) [29]. That is, the term 'sons of my womb' is a kinship through the womb of the mother that defines kindred bonds and the unity of Muslim society as a whole. This is well documented in the Qur'an (silat alrahim) [84] and the hadith. In the local context, in terms of the nuclear family, all offspring are brothers. In the extended context, all community members are brothers, 'children of one womb.' And in the global context, all Muslims are brothers, 'children of one womb.' This metaphorical employment of the womb in Islam makes Muslims around the globe brothers. The Prophet said: "The believers [Muslims] in their mutual kindness, compassion and sympathy are just like one body; when one of the limbs suffers, the whole body responds to it with wakefulness and fever" [85].

\section{SUMMARY}

Procreation is a sacred right in Islam. Thus, children in Islam are considered a great and blessed gift of Allah. There is no religious objection in the Islamic codes of ethics to an infertile couple pursuing medical treatment for infertility. The Islamic Fiqh Council concluded that five forms of in vitro fertilization are prohibited and two are lawful under Islamic law. Although surrogacy is prohibited in Sunni Islam, the desire for children may lead couples to make decisions contrary to religious teachings. Some Muslim couples fly elsewhere and cross borders to fulfill a reproductive choice that may not be permitted in their own society or country. This has been the case for an unknown number of Muslim Sunni couples from different Middle East countries who have sought donor gametes in IVF clinics in Lebanon and Iran, thereby privately defying the Sunni Muslim orthodoxy in order to become parents. Although only a minority of religious authorities permits surrogacy between two cowives of the same husband or between mother and daughter, and there is still considerable debate on this matter, this new trend may be increased in the future. 
In summary, surrogacy is not allowed in Sunni Islam in any of its forms. In order to solve the problem of childlessness, Sunni Muslims are encouraged to foster orphans. Some couples choose to foster children who are close blood kin, particularly offspring of their own siblings, while some follow Khamanei's fatwa, which contradicts Sunni Muslim orthodoxy. Although this solution is costly in terms of time, money, travel, physical and physiological suffering, as well as psychological strain, the ultimate result is considered worthwhile from their perspective.

\section{REFERENCES}

[1] Qur'an. 3:6, 4:1, 6:143-144, 8:75, 13:8, 22:5, 31:34, 33:6, 47:22, 60:3, 2:228.

[2] Zaydan A. Al-madkhal li-dirasat al-shari'a al-islamiya. Baghdad: Maktabat al-Quds 1981

[3] Sunan al-Nasai. Al-Qahira: Maktabat al-tarbiya al-islamiya.1990; 6: 65 .

[4] Serour G. Islamic perspectives in human reproduction. Reprod Biomed Online 2008; 17(Suppl 3): 34-8.

[5] Stedman's medical dictionary. $27^{\text {th }}$ ed. London \& New York: Lippincott Williams \& Wilkins 2000; p.896.

[6] Ebrahim A. Abortion, birth control and surrogate parenting: an islamic perspective. Indianapolis: American Trust Publications 1989.

[7] O'Donnell E. Iran, retreats and surprising advances: infertile in Iran. Le Monde Diplomatique 2008 April 9. Available at: http://mondediplo.com/2008/04/15iran[Accessed on 19 June 2008].

[8] Serour G. Reproduction choice: A Muslim perspective. In Harris J, Holm S, Eds. The Future of Human Reproduction: Ethics, Choice and Regulation. Oxford: Clarendon Press 1998; pp.191-202.

[9] Boivin J, Bunting L, Collins JA, Nygren KG. International estimates of infertility prevalence and treatment-seeking: potential need and demand for infertility medical care. Hum Reprod 2007; 22: $1506-12$.

[10] Inhorn M. The new Arab man: emergent masculinities, technologies, and islam in the Middle East. Princeton: Princeton University Press 2012.

[11] Van Balen F, Bos HMW. Infertility, culture, and psychology in worldwide perspective. J Reproductive Infant Psychol 2004; 22 (4): 245-7.

[12] Miller MC. The Psychological impact of infertility and its treatment. Harv Ment Health Lett 2009; 25(11): 1-3.

[13] Van Rooij F, Van Balen F, Hermanns J. A review of Islamic middle eastern migrants: Traditional and religion cultural beliefs about procreation in the context of infertility treatment. J Reprod Infant Psychol 2004; 22(4): 321-31.

[14] Guz H, Ozkan G, Sarisoy A, Yanik F, Yanik A. Psychiatric symptoms in Turkish infertile women. J Psychosom Obstet Gynaecol 2003; 24: 267-71.

[15] Delaney C. The seed and the soil: Gender and cosmology in Turkish village society. Berkeley: University of California Press 1991.

[16] Rodriquez M PM, Manstead ASR, Fischer AH. Honor in Mediterranean and Northern Europe. J Cross-Cult Psychol 2002; 33: 16-36.

[17] Abu-Rabia A, Elbedour S, Scham S. Polygyny and Post-nomadism among the Bedouin in Israel. Anthropol Middle East 2008; 3(2): 20-37.

[18] Van Balen F, Inhorn MC. Introduction-interpreting infertility: A view from the social sciences In: Inhorn MC, Van Balen F, Eds. Infertility around the Globe: New Thinking on Childlessness, Gender, and Reproductive Technologies. Berkeley: University of California Press 2002; pp. 3-23.

[19] Abu-Rabia A. The Evil Eye and Cultural Beliefs among the Bedouin Tribes of the Negev, Middle East. Folklore 2005; 116: 241-54.

[20] Inhorn M. Local babies, global science: Gender, religion, and in vitro fertilization in Egypt. New York: Routledge 2003.

[21] Abu-Lughod L. Veiled sentiments, honor and poetry in a Bedouin society. Berkeley and Los Angeles: University of California Press 1988.

[22] Eickelman C. Fertility and Social Change in Oman: Women's Perspectives. Middle East J 1993; 47 (4): 652-66.
[23] Compare this with the World Health Organization's definition of violence. Geneva:WHO 1996.

[24] Serour G. Attitudes and cultural perspectives on infertility and its alleviation in the Middle East area. In: Vayena E, Rowe PJ, Griffin PD, Eds. Current Practices and Controversies in Assisted Reproduction. Geneva: World Health Organization 2002; pp. 41-9.

[25] Kressel G, Abu-Rabia K. Exchange marriage among the Negev Bedouin: Between 'Urf and Shari'a, and state law. Hamizrah Hehadash 2006. XLVI: 5-23.

[26] Abu-Rabia A. Breastfeeding practices among pastoral tribes in the Middle East: a cross-cultural Study. Anthropol Middle East 2007; 2(2): 38-54.

[27] Bailey C. A culture of desert survival: Bedouin proverbs from Sinai and the Negev. New Haven: Yale University Press 2004.

[28] Genesis 16, 30 .

[29] Smith R. Kinship and marriage in early Arabia. Boston: Beacon Press 1976.

[30] Ibn Manzur. In: Ibn Mukarram M, Ed. Lisan al-Lisan: Tahdhib Lisan al-‘Arab, Beirut: Dar al-Kutub al-Ilmiyah 1993; p.90.

[31] Peters E. The Bedouin of Cyrenaica: Studies in personal and corporate power. Cambridge: Cambridge University Press 1990.

[32] Ibid. Impotence is a special case, because it is dishonorable for a woman to remain the wife to an impotent man. She cannot divorce him, but her father can insist on a witnessed test of impotency and, if it is proven, the husband is compelled to divorce her (Peters 1990:193, 293).

[33] Abu-Rabia A. Folk medicine among the Bedouin tribes in the Negev. Sede Boqer: Ben-Gurion University of the Negev 1983.

[34] Doumato EA . Getting God's ear: Women, Islam, and healing in Saudi Arabia and the Gulf. New York: Columbia University Press 2000.

[35] Krispil N. Medicinal plants in Israel and throughout the world The complete guide. Or Yehuda: Hed Arzi Publishing House 2000.

[36] Al-Jawziyya : al-Tib al-Nabawi (The Medicine of the Prophet) Translated by Penelope Johnstone. Cambridge: The Islamic Texts Society 1998 .

[37] Shiloh Ailon. The System of Medicine in Middle East Culture. Middle East J 1961; 15: 277-88.

[38] Pillsbury BL. Traditional health care in the Near East. Washington, DC: U.S. Agency for International Development 1978.

[39] Fadlalla HA. Modest women, deceptive jinn: Perceptions of foreignness, danger and disease among the Hadenowa of Eastern Sudan. USA: Harvard Center for Population and Development Studies, Working Paper Series 2002.

[40] Sahih al-Bukhari. The Book of Medicine Vol. 5. Edited and translated by Muhammad Muhsin Khan, al-Madina al-Munauwara: Islamic University 1974: 395.

[41] First 'test-tube baby' across the world including the Middle East countries, see [20], [70].

[42] Quran. 22:5

[43] Ghuwaybah S. Al-mutajarh bil-umumah wa-bay' al-'ada' albasharia. Qahiro: maktabat adbuli al-saghir, 1999; 29-41, 74.

[44] Salamah Z. Atfal al-Anabib: bayna al-'ilm wa-l-shari'a. Amman: alDar al 'Arabiyya lil-'Ulum1998.

[45] For more information, see note 6.

[46] Quran. 86:5-7.

[47] Atighetchi D. Islamic bioethics: Problems and perspectives. Dordrecht: Springer 2009.

[48] Rispler-Chaim V. Islamic medical ethics in the twentieth century. Leiden: Brill 1993.

[49] The Islamic Fiqh Council 1995: 306-307.

[50] Shaltut M. Al-Fatawa: dirasah li-mushkilat al-Muslim al-mu'asir fi hayatih al-yawmiyah wa-al-'ammah. Cairo: Dar al-Shuruq 1975.

[51] Among the Sunni Muslims there are four schools of thought: the Hanafi, the Shafi'i, the Hanbali, and the Maliki.

[52] Taj al'Arus- al-Zabidi, al-Qahira: maktabat al-thaqafah aldiniyah,.al-Qāhirah: Maktabat al-Thaqāfah al-Dīnīyah 2005; 3: pp. 366-7.

[53] Husain, Fatima. Reproductive issues from the Islamic perspective. Hum Fertil 2000; 3: 124-8.

[54] The Islamic Fiqh Council 1985; 161-8.

[55] Altorki S. Milk-kinship in Arab society: An unexplored problem in the ethnography of marriage. Ethnology 1980; XIX (2): 233-44.

[56] Joseph S. Gender and citizenship in the Middle East. Middle East Rep 1996: 4-10. 
[57] Balfour G. Women's health matters. Women Health Matters Netw 2005; 3: 366-7.

[58] Islamonline.net. Islam's stance on adoption,5.12.2001 Available at http://fatwa.islamweb.net/fatwa/index.php?page=showfatwa\&Opti on=FatwaId $\& I d=58889$

[59] al-Qaradawi, Y. Fatwa, al-Qahirah: Kotobarabia 2007.

[60] Fatwa no. 4380. Available at http://fatwa.islamweb.net/fatwa/index.php?page $=$ showfatwa\&Option $=$ FatwaId \&lang $=A \& I d=4380$

[61] Moringa aptera (al-ban). The bough of the horseradish tree is a symbol of beauty among the Arabs in the Middle East. The leaves, flowers, and fruit are eaten as a vegetable, and oil expressed from the seeds is used in salads. The seeds are used for medicinal and alimentary use, to ease pain in the anus, headache, fever, and to ease labor in childbirth.

[62] Hadith No. 825.

[63] Al-Qaradawi Y. Al-Halal wal-Haram fi al-Islam (The Lawful and the Prohibited in Islam). Beirut: al-Maktab al-Islami 2000.

[64] Al-Qaradawi Y. Fatawa Mu'asirah (Al-Qaradawi's Contemporary Fatawa). Beirut: al-Maktab al-Islami, 2000.

[65] Dr. Ali Gommah, Al-Azhar, member of the IWCDR's women and children committee. On August 3, 2004, the Islamic Research Association (IRA) of Al-Azhar Al-Sharif ratified the 'Children's Charter in Islam,' drawn up by the Islamic World Council for Dawaa and Relief (IWCDR) Committee of Women and Children, in response to the United Nations Children's Charter (April 2, 2004). The charter was drawn up by the elite of Arab and Muslim intelligentsia, including Dr. Yusuf al-Qaradawi, Dr. Mohammad Emara, Dr. Ali Gommah, Dr. Ahmad al-Assal, Dr. Soad Salih and Dr. Fathi Lashin).

[66] Viewing the Islamic religion largely as a way of life, in which their prized code of honor must be a component, the Bedouin proverb says: "He who has no honor has no religion- alli ma lih sharaf ma lih diyn" [27].

[67] Sheikh Ahmad Kutty, a senior lecturer and Islamic scholar at the Islamic Institute of Toronto, Ontario, Canada: May 19, 2003.

[68] Ragon H. Surrogate motherhood: Conception in the heart. Boulder, CO: Westview Press 1994.

[69] Cook R, Sclater SD, Kagans F, Eds. Surrogate motherhood. Oxford and Portland Oregon: Hart Publishing 2003.

[70] Clarke M. Children of the revolution: 'Ali Khamen'i's liberal views on in vitro fertilization. Br J Middle East Stud 2007; 34(3): 287303.
[71] Dolgin J. Defining the family: Law, technology, and reproduction in an uneasy Age. New York: New York University Press 1997.

[72] Khamane'i A. Ajwibat al-istiftā'āt (Answers for fatwas), (al-juz' II, al-Mu'āmālat, su'āl 194), Beirut: al-Dār al-Islāmiyya 2003.

[73] Tremayne S. Law, ethics, and donor technologies in Shi'a Iran. In: Birenbaum-Carmeli D, Inhorn MC, Eds. Assisting reproduction, testing genes: Global encounters with new biotechnologies. New York: Berghahn Books 2009.

[74] Temporary marriage (mut'a) is forbidden in Sunni Islam.

[75] Haeri S. Law of desire: temporary marriage in Shi'ite Iran. Syracuse: Syracuse University Press 1989.

[76] Inhorn M. Islam, IVF and everyday Life in the Middle East: the making of Sunni versus Shi'ite test-tube babies. Anthropol Middle East 2006; 1(1): 42-50.

[77] Inhorn M. Making Muslim babies: IVF and gamete donation in Sunni versus Shi'a Islam. Cult Med Psychiatry 2006; 30: 427-50.

[78] Tamam H. 4.4.2001. Hiring wombs between medicine and politics. Available at: http://www.onislam.net/arabic/health-a-science/health/91784-2001-04-04\%2000-00-00.html

[79] Farag F. Legislating morality, al-Ahram Weekly on-line, No. 534, May 17-23, 2001. Available at: http://weekly.ahram.org.eg/2001/534/feat 1. htm

[80] Serour G. Contemporary ethical dilemmas in assisted reproduction. In: Shinfield F, Sureau C, Eds. Religious Perspectives of Ethical Issues in ART. UK: Informa Health Care 2006; pp.99-114.

[81] Quran. In the Qur'an two prescribed objects of ihsan are orphans and the needy [1]. In defining a life of goodness, the Bedouin say: "The bases of beneficence are three: Raising an orphan, helping the poor, and doing justice- usul al-ihsan thalatheh: tarbiyyat al-yetim wimsa'adat al-fagir, u-sun'a al-hagg" [27].

[82] Kandela P. Uterine transplantation failure causes Saudi Arabian government clampdown. Lancet 2000; 356 (9232): 838.

[83] A menopausal uterus can function normally under hormonal stimulation and, once transplanted into recipient without rejection, could receive an ovum released by the recipient and fertilized by her husband's sperm $[82,43]$.

[84] Silat al-rahim. womb relatives (Qur'an:3:6, 4:1, 6:143-144, 8:75, 13:8, 22:5, 31:34, 33:6, 47:22, 60:3, 2:228).

[85] Sahih Muslim. Available at: http://www.bookofsigns.org/2010/ 11/teachings-of-the-prophet-on-the-conduct-of-the-believers-withone-another/

\section{(C) Aref Abu-Rabia; Licensee Bentham Open.}

This is an open access article licensed under the terms of the Creative Commons Attribution Non-Commercial License (http://creativecommons.org/licenses/ by-nc/3.0/) which permits unrestricted, non-commercial use, distribution and reproduction in any medium, provided the work is properly cited. 